This item was submitted to Loughborough's Research Repository by the author.

Items in Figshare are protected by copyright, with all rights reserved, unless otherwise indicated.

\title{
Antecedents of corporate entrepreneurship in SMEs: evidence from an emerging economy
}

\section{PLEASE CITE THE PUBLISHED VERSION}

http://dx.doi.org/10.1111/jsbm.12269

\section{PUBLISHER}

(C) International Council for Small Business. Published by Wiley.

\section{VERSION}

AM (Accepted Manuscript)

\section{PUBLISHER STATEMENT}

This work is made available according to the conditions of the Creative Commons Attribution-NonCommercialNoDerivatives 4.0 International (CC BY-NC-ND 4.0) licence. Full details of this licence are available at: https://creativecommons.org/licenses/by-nc-nd/4.0/

\section{LICENCE}

CC BY-NC-ND 4.0

\section{REPOSITORY RECORD}

Hughes, Mathew, and Michael Mustafa. 2019. "Antecedents of Corporate Entrepreneurship in Smes: Evidence from an Emerging Economy”. figshare. https://hdl.handle.net/2134/24334. 


\title{
Antecedents of Corporate Entrepreneurship in SMEs: Evidence from an emerging economy
}

\author{
Mathew Hughes \\ Durham University \\ Michael Mustafa \\ University of Nottingham Malaysia \\ Accepted for publication at Journal of Small Business Management
}

\begin{abstract}
Corporate Entrepreneurship research has reached a certain degree of consensus around five core internal antecedents that enable CE. But, consensus remains focused on large-sized firms in Western economies. Using institutional theory, we argue that contextual factors may undermine the viability of internal antecedents in emerging economy contexts. Our qualitative study shows that the organization of the internal environments for CE among service sector Kenyan SMEs is much more interactive and complex than currently presented in the literature. Specifically cultural and contextual factors appear to influence the extent to which the antecedents are able to produce CE activity. Our findings provide a more fine-grained depiction of the internal environment for CE in emerging economy SMEs.
\end{abstract}

\section{INTRODUCTION}

What enables corporate entrepreneurship in emerging economy SMEs? Corporate Entrepreneurship (CE) has attracted scholarly interest because it directs firms to recognize and exploit new opportunities (Ireland, Covin, and Kuratko 2009) through innovative and proactive behavior (Dess, Lumpkin, and McGee 1999) that can revitalize and increase the innovativeness of existing organizations (Covin and Miles 2007; Ireland et al. 2009; Zahra, Jennings, and Kuratko 1999). Corporate entrepreneurship is necessary for firms in turbulent, dynamic or highly volatile environments, wherein strategic flexibility and innovativeness are needed to maintain competitive advantages and respond to environmental pressures (Bruton, Ahlstrom, and Obloj 2008; Yiu and Lau 2008). Emerging economies represent such a context but are characterized by competitive, market and institutional differences that condition how managers and employees make judgments about CE and perceive what conditions and actions are legitimate within their context (Ahlstrom and Bruton 2010; Hermelo and Vassolo 2010; Wan and Hoskisson 2003; Yiu and Lau 2008). Because of these crucial differences, the failure of CE research

to properly treat the context firms exist and operate in means that the present consensus among scholars 
about the antecedents of CE, developed almost exclusively in the traditional Western context, is premature and at worst may prove to be entirely wrong.

Research into the antecedents of CE (Alpkan, Bulut, Gunday, Ulusoy, and Kilic 2010; Hornsby, Kuratko, and Zahra 2002; Kuratko, Hornsby, and Covin 2014; Sebora, Theerapatvong, and Lee 2010) has converged on the importance of five antecedents creating an entrepreneurial internal firm environment

43 conducive to CE: top management support, time availability, rewards/reinforcement, work

44 discretion/autonomy, and organizational boundaries. These are said to 'prepare' the firm for CE 45 (Hornsby, Kuratko, Holt, and Wales 2013a). Yet empirical support for some of these antecedents remains mixed (Hornsby et al. 2013a) and scholars have questioned their applicability to CE in non-traditional

47 economic and organizational contexts and across different regions (Hornsby, Peña-Legazkue, and 48 Guerrero 2013b; Phan, Wright, Ucbasaran, and Tan 2009). A new group of studies have since called for an examination of what enables firms to achieve CE in emerging economy contexts (Hornsby et al. 2013b; Hoskisson, Eden, Lau, and Wright 2000). An emerging economy context holds very different institutional characteristics compared to the traditional Western origin of CE studies. For example, a

52 collectivist culture, authoritarianism, and deference to authority prevalent in African nations can shape 53 indifference toward entrepreneurship among African employees (Jackson, Kenneth, and Serap 2008; 54 Morris, Davis, and Allen 1994; van Wyk and Adonisi 2012). Institutional differences and institution55 specific conditions can also directly affect strategic choices available at the level of the emerging 56 economy firm (Young, Tsai, Wang, Liu, and Ahlstrom 2014). It is far from certain that the antecedents of 57 CE conceived in the tradition of mid-to-large-sized established firms in Western economies transfer to 58 different economic and institutional contexts. In addition to the institutional context, studies must also account for SMEs as a new generation of research shows that SMEs operate differently to their established, larger counterparts in terms of entrepreneurship (Kraus 2011; Zellweger and Sieger 2012) and do not readily fit models built from

62 research into such firms (Sine, Mitsuhashi, and Kirsch 2006). Sine et al. (2006) lament the false logic that 63 SMEs rely on flexibility and a lack of formalization for their success, arguing that these initial conditions 
are merely a reaction to opportunities in a changing environment. Citing Stinchcombe (1965), Sine et al. (2006) suggest that SMEs need less flexibility and more role specificity to overcome a 'structural liability of newness'. Such ideas sit orthogonally to the causal mechanisms of CE presented in the literature (Hornsby et al., 2002, 2009; 2013a, 2014).

Zahra and Wright (2011) express concern of the failure of entrepreneurship research to engage more fully with context when studying entrepreneurship, arguing the need to pay careful attention to the nature of the context firms operate in to best develop theory. Beyond the institutional and organizational, industry context has also been particular ignored, left as little more than a control variable in most studies. The service sector has specifically languished behind its contemporaries in receiving research attention, and scholars have called for studies that demonstrate how entrepreneurship takes place in service firms to discredit the notion that these result from mere intuition or luck (Storey and Hughes 2013). Thus, to meet the challenge set out by Hornsby et al. (2013b), Hoskisson et al. (2000), Phan et al. (2009), Sine et al. (2006), and Zahra and Wright (2011), the research questions we address are: (1) Is the current conceptualization of the five antecedents of an internal environment for CE applicable and relevant in the context of service sector SMEs in an emerging economy? (2) What new or different antecedents to CE are seen in the context of service sector SMEs in an emerging economy?

Focusing on these key questions, we draw on an institutional perspective on CE and argue that (1) institutional and cultural factors may undermine the viability of present antecedents to enable CE in emerging economy contexts, and that (2) the resource challenges in this context exacerbate those already faced by service sector SMEs, requiring them to rethink how they enable CE. We examine these issues through a qualitative investigation of service sector SMEs located in Kenya. Kenya has been developing rapidly and represents an important gateway to Africa (Jackson et al. 2008). Part of this growth has been attributed to the rapid rise and proliferation of local SMEs (Matanda 2012; Ronge, Ndirangu, and Nyangito 2002). Despite growing competition (locally and from abroad through international foreign investments) and limited resources, many Kenyan SMEs remain highly dynamic, innovative, and successful, suggesting that CE is rife among them (Jackson et al. 2008). 
This article makes three contributions. First, we offer a theoretical contribution that affords

91 scholars new and refined insights into the antecedents of CE within the context of emerging economy

92 service-sector SMEs, and from a theoretical position unaccustomed among studies of the antecedents of

93 CE. Our study contributes theoretical development towards a more holistic or complete picture of what

94 drives or constrains CE as called for by Hornsby et al. (2013b) and Hoskisson et al. (2000). Second, we

95 offer an empirical contribution by extending the geographic and contextual reach of empirical knowledge

96 on CE called for by Phan et al. (2009) and Zahra and Wright (2011). Studies to date have arrived at a

97 consensus on the antecedents of an internal environment productive for CE almost exclusively in the

98 context of Western developed economies. By accounting for how the institutional and business context of

99 emerging economy settings reshape or revise these antecedents, our data enlarge scholarly and managerial

100 understanding of how existing ventures become more competitive in emerging economies. Finally, we

101 offer a small methodological contribution via our research design. Zahra et al. (1999) called for better

102 theory building in CE research through the adoption of qualitative methodology. Qualitative methodology

103 enables a much better understanding of the 'how' and 'why' of CE and is especially useful in contexts

104 where both theoretical and empirical knowledge are thin and immature. Using a qualitative approach

105 allows us to overcome problems associated with the use of single-respondent survey data in

106 entrepreneurship research and address the de-contextualization of CE antecedents by prior studies. Our

107 protocols can also help researchers develop more context-sensitive treatments of CE in future.

108 As scholars we do not have a theoretical framework customized to SMEs or to the emerging 109 economy context that can help us to understand and explain their CE. Appreciating how CE is achieved 110 and practiced among SMEs in emerging economies will help scholars develop better theories and help 111 managers and policy makers arrive at better customized prescriptions to improve the competitiveness of 112 these firms. This study represents a first attempt to consider whether, how, and in what ways the 113 'established' antecedents of CE are applicable in emerging economy SMEs in Kenya and what additional 114 factors are important for an internal environment for CE in emerging economy SMEs. 

THE INTERNAL ANTECEDENTS FOR CORPORATE ENTREPRENEURSHIP

Defined as a "process wherein an individual or a group of individuals, in association with an existing organization, create a new organization or instigate renewal or innovation within that organization" (Sharma and Chrisman 1999: p.26), CE broadly describes activities related to the development and pursuit of new business ideas and opportunities within established firms. This definition

122 builds on earlier statements by Guth and Ginsberg (1990) that CE encompasses new corporate venturing 123 and strategic renewal. Later work by Morris, Kuratko and Covin (2011) added a third dimension in the 124 form of strategic entrepreneurship, in which a firm favors, pursues, and implements high-impact 125 innovation. It is the internal environment of the firm that originates, enables, and incubates CE activities that may go on to represent these larger outcomes (Hornsby et al. 2013a). Although various definitions of 127 CE exist, we adopt Sharma and Chrisman's (1999) definition, as it is sufficiently broad to avoid 128 excluding important issues that may otherwise go undetected. This is also appropriate given that what constitutes CE and its outcomes in emerging economy and service sector SMEs is neither well-known nor well-circumscribed as yet (Kraus 2011).

Firms that exhibit CE are typically viewed as dynamic, flexible entities prepared to take 132 advantage of new business opportunities as they appear (Kuratko, Goldsby and Hornsby 2012). Firms 133 also stand to gain improvements in business performance from CE with longstanding longitudinal 134 evidence anchoring this belief (Zahra and Covin 1995). Uncontrollable factors such as environmental 135 hostility and rapid technological advancement may push entrepreneurial activity to take place inside an 136 organization (Bradley, Aldrich, Shepherd, and Wiklund 2011), because successfully competing in such 137 environments requires a strategic intent towards entrepreneurial activity (Ireland et al. 2009; Morris et al. 138 2011). Such a strategic intent can be achieved through purposeful managerial actions to create a pro-CE 139 organizational architecture (Hornsby et al. 2013a; Ireland et al. 2009). Assessing and determining a firm’s 140 current organizational environment or state of 'organizational preparedness for $C E$ ' represents an 141 important element for successfully implementing a CE strategy (Hornsby et al. 2013a, p.937). 

al. 2002, 2013a, 2014), and provides a means of profiling a firm's internal environment for CE. The five antecedents are deemed necessary for an internal environment favorable for CE behavior to emerge. These five antecedents are: top management support (the extent to which the top managers support,

146 facilitate, and promote individual and collective entrepreneurial behaviors), work discretion/autonomy 147 (the extent to which top managers provide decision making latitude, freedom from excessive oversight, 148 and authority and responsibility to lower level employees), rewards/reinforcement (the extent to which 149 organizations are willing to use systems that reward employees based on entrepreneurial activity), time 150 availability (the extent to which employees are expected to invest 'slack' time on their most salient tasks 151 given their roles and responsibilities), and organizational boundaries (the extent to which the organizational structure enhances the flow of information between the external environment and the organization and among its departments/divisions).

Recent efforts to examine the CEAI have started to apply the instrument to different settings (Alpkan et al. 2010; de Villiers-Scheepers 2012; Holt et al. 2007; Sebora et al. 2010), but still emphasize its current form in revised theoretical and conceptual frameworks of CE (e.g., Ireland et al. 2009; 157 Kuratko, Ireland, Covin, and Hornsby 2005). Empirical support has been found for the antecedents of management support, work discretion/autonomy, and rewards/reinforcement for a range of entrepreneurial activity (Holt, Rutherford, and Clohessy 2007; Hornsby et al. 2009; Sebora et al. 2010). But support for the time availability dimension is lacking (Holt et al. 2007; Hornsby et al. 2009), while 161 the organizational boundaries dimension suffers from measurement problems (Holt et al. 2007; Hornsby 162 et al. 2009). The levels and types of resources that an organization has access to (Hornsby et al. 2013a) 163 and the possible interactions among dimensions have also not received attention. Thus, further 164 consideration needs to be given to other meaningful dimensions and the context in which these 165 dimensions become meaningful.

A particular problem exists in the present de-contextualization of the antecedents of CE. This in 167 part stems from the dominance of quantitative methodologies in the research into these antecedents (and 
CE in general) (de Villiers-Scheepers 2012; Hornsby et al. 2009; Sebora et al. 2010) and theoretical assumptions which are based on the experiences of larger firms from developed economies such as the U.S. (Hornsby et al. 2002; Rutherford and Holt 2007) and Canada (Hornsby, Kuratko and Montagno 1999). Therefore, rather than being a simple function of the five 'established' antecedents, further

172 differences in the makeup of those dimensions and in their influence on enabling CE may come from 173 contextual differences among different types of firms in different types of economies. Cause for concern 174 also comes from studies into SMEs. In examining the CEAI measure in the context of a knowledge175 intensive European SMEs, Christensen (2005) noted that the five existing antecedents were not sufficient 176 in enabling entrepreneurship in such contexts. Differences across cultural norms and values may further 177 yield differences in the patterns and conceptualizations of the existing CEAI dimensions (de Villiers178 Scheepers 2012; Hornsby et al. 2013b).

Outside of the CEAI measure itself and looking at the effects of entrepreneurial orientation, Frank, Kessler, and Fink (2010) reported that a positive connection between firm entrepreneurial behavior and business performance only occurred in cases in which a dynamic environment is combined with high access to financial capital and when a stable environment is combined with low access to financial capital. The findings of Frank et al. (2010) stand in contrast to existing observations about SMEs in emerging economies. For example, despite growing competition and complex operating environments (i.e., a dynamic environment), and limited access to and availability of resources (including financial), many emerging economy SMEs remain vibrant, innovative and successful, suggesting that CE is rife among them (Jackson et al. 2008). For these reasons, the paper now moves to analyze the potential antecedents of CE in the context of emerging economy SMEs, and Kenya in particular.

\section{ANTECEDENTS TO CORPORATE ENTREPRENEURSHIP IN EMERGING ECONOMY SMES}

The benefits and value of CE are not restricted to large established firms from developed market economies (Hitt, Ireland, Sirmon and Trahms 2011). CE also holds promise for SMEs in emerging economy contexts (Gómez-Haro, Aragón-Correa, and Cordón-Pozo 2011; Lou and Junkunc 2008) as it 
offers a means through which emerging economy SMEs can (re)vitalize activities, reconfigure resources, and set in place the entrepreneurial mindsets indispensable to competing effectively in such highly turbulent environments (de Villiers-Schemers 2012; Yiu and Lau 2008). But the body of knowledge on how CE is enabled in such firms in such contexts remains thin (Phan et al. 2009). entrepreneurial behavior. If so, the organizational antecedents that encourage and support CE might then be valid across firms of any size. However, unlike their larger counterparts, SMEs compete in competitive markets with only limited resources (Carrier 1996; Zahra and Pearce 1994) and exhibit different internal organizational challenges brought about by growth. Such challenges may impact how support for CE is organized in SMEs. For example, Sebora et al. (2010) only found the CEAI dimensions of management support and rewards (through recognition) to be significantly related to improving CE in Thai SMEs; owner/manager leadership style (Kantur and Iseri-Say 2013) and the nature of their personal relationships with employees have been suggested as more important determinants of CE among SMEs

207 (Castrogiovanni, Urbano, and Loras 2011); and Sine et al. (2006) found the classic Burns and Stalker view that firms, irrespective of size, benefit from an 'organic' structure in dynamic environments to be misleading for young and small firms.

211 perceptions of the internal environment for CE (de Villiers-Scheepers 2012; van Wyk and Adonisi 2012).

212 This can be explained by institutional theory, and prior research has shown that the institutional environment can affect the nature and scope of entrepreneurial activities among firms (Bruton et al. 2010;

214 Gómez-Haro et al. 2011; Ireland et al. 2009). Institutions refer to the cognitive, normative, and regulative 215 structures that provide stability and meaning to behavior (Scott 1995). Institutions can be formal 216 (regulations, normative, contracts, etc.) or informal (codes of conduct, attitudes, values, etc.), but informal 217 institutions are particularly important in that they also provide behavioral short cuts for individuals and 218 organizations as they 'come from socially transmitted information and are a part of the heritage that we 219 call culture' (North 1990, p.37). An institutional perspective on CE proposes that the behaviors exhibited 
220 by firms, and the decisions made by their managers and employees, are shaped by formal and informal

221 institutional arrangements (Bruton, Ahlstrom, and Li 2010; Gómez-Haro et al. 2011; Hoskisson et al.

222 2000; Ireland et al. 2009; Puffer, McCarthy, and Boisot 2010). Thus, how the CEAI dimensions are

223 perceived by individuals and how CE is enacted in response to those institutional arrangements can be

224 expected to differ between SMEs in emerging and developed economies (Bruton, Ahlstrom, and Li 2010;

225 Yiu and Lau 2008).

226 Kenya represents a growing emerging economy, wherein local SMEs represent a critical vehicle

227 for employment creation and poverty reduction. Many Kenyan SMEs continue to find themselves

228 competing in highly globalized environments, but with limited access to critical resources (Bowen and

229 Mureithi 2009; Mwobobia 2012). Such resource constraints suggest that Kenyan SMEs are more likely to

230 face proportionately greater risk from innovation failure than larger firms and receive fewer rewards for

231 being entrepreneurial (Sorescu and Spanjol 2003). Additionally, the availability of financial resources has

232 been shown to influence African SME managers' perceptions of innovation (Freel 2005), while the

233 quality of human capital (Hausman 2005; Kiggundu 1988) has been found to affect the innovative

234 behavior of African SMEs (Blunt and Jones 1992; Jackson et al. 2008). In short, wider resource

235 constraints may make it difficult for emerging economy SMEs to organize and provide support for

236 entrepreneurial initiatives (Frank et al. 2010).

237

The service sector accounts for about 63 percent of Kenya’s Gross Domestic Product (GDP) and

238 has historically led Kenya’s economic growth (Library of Congress 2007). The limited research into firm-

239 level entrepreneurship among service sector firms has tended to re-confirm the benefits of CE for firm

240 performance (Kraus 2011). Research has also shown service sector SMEs to have significantly higher

241 levels of entrepreneurship than manufacturing firms (Rigtering, Kraus, Eggers, and Jensen 2014). In

242 Kenya, manufacturing accounts for as little as 14 percent of GDP (Library of Congress 2007). Scholars

243 have suggested that the specific characteristics of service sector firms such as the intangibility of their

244 products (Bateson 1992) and their simultaneous production and consumption (Lovelock 1984), make 
service sector firms more labor- and less capital-intensive than manufacturing sector firms. This suggests that the service sector context might further influence the antecedents of CE in these firms (Kraus 2011). Differences in normative and cognitive factors within the institutional context and challenges faced SMEs within the service sector context are likely to shape managers' and employees’ perceptions of CE and the CEAI dimensions (Morris et al. 1994). For example, Hornsby et al. (2009) and Carrier (1996) suggest that effective reward systems should emphasize individual responsibility and provide resultsbased incentives to spur entrepreneurial activity. However, such assumptions many not hold true in emerging contexts such as Kenya, in which collectivist principles often dominate. A strongly collectivist environment may give rise to an anti-entrepreneurial bias, wherein group performance and reward systems can encourage ‘free-rider’ or ‘social loafing’ syndromes (Jackson et al. 2008; Morris et al. 1994). Moreover, Monsen, Patzelt and Saxton (2010) reported a complex interaction among perceived employment risk, profit sharing, and the extra effort employees are willing to exert when participating in new initiatives. With respect to Kenya, Blunt and Jones (1986) found that managers assigned the highest importance to security needs. Therefore reward systems which emphasize individual responsibility and results-based incentives (as seen in present CE antecedents) (Fry 1987; Sathe 1985) may have little effect in spurring CE in such contexts.

Hornsby et al. (2002) and Lumpkin and Dess (1996) also proposed that work discretion and autonomy are needed to encourage entrepreneurial endeavor by individuals within firms. This however assumes that individuals are mindful to adopt such practices. Kiggundu (1988) and others noted that management philosophies in Kenya are dominated by principles of classical management, in which there are sharp distinctions and status differences between management and workers. As such Kenyan employees are expected to do their work and obey management's instructions and directives (Beugré and Offodile 2001; Jackson et al. 2008; Kamoche 2011). Unsurprisingly, in their study of the CEAI dimensions in South Africa, van Wyk and Adonisi (2012) found that such authoritarianism correlated negatively with CE. Thus, differences in cultural attitudes are likely to affect how work discretion is interpreted by subordinates and ultimately practiced by superiors. 
Time availability for managers is seen as an important resource for generating entrepreneurial

272 outcomes (Stopford and Baden-Fuller 1994). While CE authors (e.g., Kuratko et al. 2005) may argue that

273 in entrepreneurial work environments, employees should be allowed to conduct creative, entrepreneurial

274 experiments during a limited portion of their work time, the reality often falls short of this ideal. This is

275 likely to hold true in the context of emerging economy service sector SMEs, where employees and firms

276 find themselves dealing with fast-paced market changes and dynamic competition along with traditional

277 mindsets towards management (Bruton, Ahlstrom, and Li 2010; Jackson et al. 2008; Yiu and Lau 2008).

278 Slack time for entrepreneurial initiatives among African employees may be meaningless because of

279 cultural preferences towards focusing on immediate tasks with known outcomes coupled with respect

280 towards authority figures (Nyambegera, Sparrow, and Daniels 2000). Indeed, both de Villiers-Scheepers

281 (2012) and van Wyk and Adonisi (2012) did not find a significant relationship between time availability

282 and CE.

In sum, theoretical explanations suggest that differences among CE antecedents are likely to arise

284 in an emerging economy service sector SME context. To investigate whether and how the antecedents might be relevant or not in firms that do not fit the traditional Western prototype, the paper will now move to discuss the research methodology used to investigate these issues.

\section{RESEARCH DESIGN AND METHODOLOGY}

Hornsby et al. (2002), Zahra and Wright (2011), and Zahra et al. (1999) highlighted the need for qualitative research to better understand the organizational and cultural context in which firm-level entrepreneurship takes place. We adopted a multiple case study approach in order to achieve our research objectives (Yin 2003). According to Yin (2003), 'the case study contributes uniquely to our knowledge of 292 individual, organizational, social, and political phenomena' and 'the distinctive need for case studies 293 arises out of the desire to understand complex social phenomena' (p. 14). The case study method is 294 increasingly used to examine firm-level entrepreneurship (Peltola 2012; Sebora et al. 2010) and has 295 recently been used by several studies to examine constructs such as entrepreneurial orientation (Zellweger 296 and Sieger 2012) and the internal antecedents of CE (Christensen 2005; Kantur and Iseri-Say 2013). This 
method is well-suited to understanding the antecedents of CE in the context of emerging economy service sector SMEs.

In line with our research objectives, we adopted a criterion based purposive sampling strategy (Patton 1990). This approach requires that potential case firms be selected based on meeting specific criterion and looks for cases which are information rich. We searched for SMEs in emerging markets with 302 rich entrepreneurial histories as a means of investigating the internal antecedents that drive their CE. 303 Accordingly, we also looked for potential cases that demonstrated a variety of specific CE related 304 initiatives such as corporate venturing, strategic renewal, and product and process innovation since their 305 inception (see Table 1 for specific examples). Drawing on information from Kenyan Institute of 306 Management's Company of the Year Awards database, we specifically looked for firms that meet the 307 following criteria: (1) were of small or medium size, (2) initiated and implemented two or more CE 308 initiatives (regarding the product, service, process or strategic renewal) within the past five years, and (3) were part of the services sector.

We chose the Kenyan services sector as the research site for our empirical investigation because

311 it has been described as one of the most entrepreneurially-oriented sectors of the Kenyan economy 312 (Nyanjom and Ong'olo 2012). Through active government support and through opening up foreign 313 competition, the sector has undergone profound political, economic, and social changes over the past 15 314 years (Balistreri, Rutherford, and Tarr 2009; Nyanjom and Ong'olo 2012). As such, SMEs in this sector 315 have found themselves making significant adjustments to their business processes and strategies in order 316 to remain competitive, resulting in the emergence of several highly innovative and entrepreneurial firms 317 within the sector.

Fourteen CEOs/Owners of potential firms in Nairobi and Mombasa were contacted regarding 319 their participation in the study. After initial discussion with the CEOs/Owners, it was determined that 320 only 6 of the 14 potential cases met all three of our criteria. The final selection of cases was carried out by 321 considering the variety of industries in which the firms operated in, the possibility of accessing the 322 necessary sources of information and in providing contrasting examples. The four cases selected were 
323 KeTours, SafePack, InfoComm and GoodSell, and represented various industries within the services 324 sector: Tourism (KeTours), Retail/sales (GoodSell), ICT (InfoComm) and Health \& Safety and 325 Distribution (SafePack).

326

\section{INSERT TABLE 1 ABOUT HERE}

We assessed the internal antecedents for CE among Kenyan SMEs using a combination of firm behavior and managerial and employee perceptions drawn from both primary and secondary data (Yin 1984;2003;2014). Primary data were collected via a series of semi-structured interviews with 3 to 5 individuals from each case firm whom had in-depth knowledge concerning the firms' activities and processes. Environmental changes and organizational factors can be perceived differently by managers/owners and employees alike (Hornsby et al. 2009). We thereby avoided the danger of key informant bias by asking questions of both managers and employees. All interviews were conducted in English by the lead author and a research assistant, lasted between 45 minutes to 2 hours in length and were audio taped. An interview protocol based around Hornsby et al.’s (2002) conceptualizations and CEAI items was developed. Some example questions include, ‘Tell me about how your organization's top management views, values and seeks to facilitate and support entrepreneurial behavior' (top management support); 'Can you explain and give examples of how your organization identifies, evaluates and rewards innovative and entrepreneurial behavior' (rewards/reinforcement); and 'How much autonomy are you given in your current job?....To what extent does your organization tolerate failure from entrepreneurial efforts' (work discretion/autonomy).

Within this schedule, follow-up questions and prompts were used to explore situations where an interviewee reported a lack of evidence for a specific activity, thereby allowing the data collection process to expand towards learning about contextual factors relevant to entrepreneurship within the firm. In addition, interviewees were specifically asked to reflect upon innovative processes and entrepreneurial activities that had taken place in their firms and how these were organized and put into place in support of 
CE. Secondary data were also collected from company websites and annual reports, and were gathered in order to map out strategic actions relevant to the subject of the study, to describe important contingencies

351 (industry, culture, or environment) relevant to the subject of the study, to document relevant outcomes in 352 this respect, and to accomplish triangulation as put forward by Yin (1984; 2003; 2014).

All interviews were carefully transcribed by one author and a research assistant. Both researchers 354 independently coded the contents of the interviews using pre-existing antecedents developed and 355 identified by Hornsby et al. (2002). We chose not to use coding software as the semi-structured nature of 356 the interviews allowed for the rapid identification of key constructs under consideration. The independent 357 coding process led to the development of case protocols approximately 24 pages in length by each 358 researcher. Additionally, tables highlighting the case firms' evolution, and an overview table of the five antecedents were created to enrich the case protocols.

We sought to create a profile of each case firm's internal environment for CE using the techniques described by Zellweger and Sieger (2012). Firstly, each researcher independently evaluated the levels of the internal antecedents at the point of investigation using a nine-point scale ranging from 1 (low) to 9 (high). To avoid over specification, we formed three rating categories: low (rating 1-3), medium (rating 4-6), and high (rating 7-9), allowing each researcher to develop a graphical illustration of the five internal antecedents for CE in each case (see Figure 1). Subsequently, a rating in any one of the antecedents not only suggests the need for the development of such activities to enhance the firm's readiness for $\mathrm{CE}$, but also that the case firms' experienced difficulties in applying the particular antecedent.

Next, the two researchers met, compared their independent findings and profiles of the case firms, and discussed any discrepancies. Overall, the two researchers were able to agree upon a single profile for 371 each case as there was little disagreement among the independent examinations. Finally, both researchers 372 also considered possible shortcomings and extensions of the existing conceptualization of the antecedents, 373 resulting in a refined conceptualization located in the context of emerging economy SMEs. 
FINDINGS

\section{ANTECEDENTS OF CORPORATE ENTREPRENEURSHIP IN KENYAN SMEs}

Analysis of case data showed that a supportive organizational climate is a crucial aspect of entrepreneurial SME firms in emerging economies. However, our data indicates that our case firms perceived and successfully implemented only two of the five established antecedents of CE; namely top management support and organizational boundaries. In contrast to the prevailing view in the CE literature, 384 our case firms faced obstacles and hurdles to accommodating rewards/reinforcement, work discretion/autonomy, and time availability in CE (de Villiers-Scheepers 2012; Sebora et al. 2010). In particular our cases show that the specific profiles of the antecedents associated with successful CE in emerging economies and SMEs may also differ considerably from their Western and larger firm counterparts. Moreover, our findings also demonstrate that cultural, contextual and resource availability matter with respect to how managers can realistically put in place in an effort to spark CE. The following section and Table 2 discusses these in more detail.

\section{Top management support}

Prior research in CE focusing on larger organizations has emphasized top management support in facilitating and promoting entrepreneurial behavior through the creation of a pro-entrepreneurial 397 organizational environment and the provision of resources that people require to take entrepreneurial 398 actions (Hornsby et al. 2002; Ireland et al. 2009). The data from our cases largely supports this view for 399 SMEs in an emerging economy context. However, our data also reveals differences in how top 400 management supported CE in emerging SMEs from that of larger firms. In particular, the majority of our 
401 interviewees indicated that formalized support mechanisms such as the allocation of financial and non402 financial resources in support of new entrepreneurial efforts were either limited or non-existent. Several managerial level respondents stressed that their firms generally took a long-term 404 approach to projects and hence resources were carefully planned in advance and committed to such 405 projects only after much due diligence had taken place. Moreover, both the R\&D manager of SafePack 406 and CIO of InfoComm admitted that in an emerging economy like Kenya, procuring resources, especially 407 financial resources from the market was extremely difficult and hence their firms had to employ a 408 'conservative and cautious approach' to managing their firms' current resources stocks. Similarly 409 GoodSell's project manager stated, 'We need to constantly think of the long term goals of the company. 410 They (management) look at the company's budget very tightly and are not in the habit of freely spending 411 it.' Hence, among our case firms, the careful and diligent use of resources is a matter of priority, and 412 long-term innovation is vulnerable compared to responses to short-term business pressures. Our findings 413 here further support that a firm's interest in entrepreneurial activities can be influenced by management's 414 perceptions of resource slack and availability and its willingness to make those available. Normally, this 415 would be thought to deprive entrepreneurship within the firm, yet these case firms are known for their 416 innovation and entrepreneurship. This implies that context is fundamental to making judgments about 417 CE.

418 Observations and discussion with the respondents also highlighted the importance of informal 419 mechanisms in support of entrepreneurial activity provided by top management. Both managerial and 420 non-managerial respondents alike consistently talked about the role played by top managers in identifying 421 and personally bringing to the owners' attention promising entrepreneurial initiatives. For example, 422 KeTours' Operations and Planning Director claimed that KeTours is a place where 'when senior 423 management see that an idea has potential they are willing to quickly bring it the attention of the owners'.

424 Similarly, at both InfoComm and SafePack, top managers maintain an open door policy and encouraged 425 employees with new ideas for projects and products to come to see them directly. Also, in the case of 
InfoComm and KeTours, top management facilitated CE by informally encouraging and orchestrating the

427 interactions of individuals and teams in order to formulate new ideas or devise new projects.

The findings above resonate with Western studies in that senior management often develop the

429 vision for entrepreneurship, which stimulates the engagement of others in similar pro-entrepreneurship

430 behavior (Ireland et al. 2009). Accordingly, we find that our case firms tend to exhibited moderate to high

431 levels of top management support for CE (see Figure 1). But, our findings further suggest that such top

432 management support differs in important ways, especially with respect to exactly how they supported CE.

433 For instance, in contrast to earlier research, our findings suggest that in emerging economy SMEs,

434 financial and resource support can be limited, creating a much stronger competition for viable ideas only

435 to emerge to the surface. Our findings further highlight the importance of more informal mechanisms

436 such as espousing an entrepreneurial spirit or encouraging employee interactions in this respect.

437 Rewards/reinforcement

Numerous studies have stressed that CE can be encouraged in both large and small firms by the use of organizational systems which clearly identify and recognize entrepreneurial activity (Carrier 1996; Hornsby et al. 2002; 2013a). In general, interviewees suggest that they were cognizant of how rewards were linked to their own entrepreneurial efforts. However, in contrast to theoretical expectations, our

442 findings revealed that the majority of our case firms lacked specific organizational systems and processes to recognize and reward entrepreneurial efforts. For instance, at SafePack and GoodSell, performance 444 reviews were done in an irregular and ad-hoc manner not linked to entrepreneurial outcomes at all. 445 Moreover, in instances where there were regular performance evaluations (KeTours and InfoComm), they 446 tended to overly emphasize more immediate and easily-observable organizational goals and employee 447 behaviors. As KeTours' Operations and Planning Manager pointed out, 'the annual review is overly 448 focused on making sure we stick to protocol and are achieving our efficiency targets’.

449 Interviews with respondents further identified that their interest in engaging in entrepreneurial 450 activity was further undermined by ambiguities in recognizing entrepreneurial efforts and ultimately who 451 would benefit from them. For instance, at SafePack, evaluations were rather ambiguous, and in the case of 
452 GoodSell, cultural considerations were identified as affecting the assessors' discretion in determining 453 whether the employee was behaving entrepreneurially or not. Hence in both these cases, respondents 454 interviewed were found to be less engaged in CE related behaviors as compared to the other case firms. 455 Furthermore, our analysis of the data revealed a general perception among some respondents that 456 entrepreneurial actions on their part would only benefit the firm. One InfoComm employee explained, 'I 457 try new ideas to get new sales and when we get new customers, it's only the company that benefits, I 458 don't. Because he[manager] says it's part of my job. So what good does it do me?' As such they would 459 rather just be told what to do and achieve their individual targets rather than go out of their way to 460 generate new ideas. Compliance-related behavior is therefore seen as more beneficial despite appearing to 461 negatively impact entrepreneurial actions.

Regarding the type of rewards, we identified differences with respect to the value that our respondents attached to certain rewards as compensation for entrepreneurial behaviors. Prima facie, all case firms tended to prefer the use of non-financial reward structures to reward individuals to encourage CE. Moreover, our analysis of the data identified financial constraints and cultural attitudes as influencing the firms' choices of rewards. As the founder of KeTours commented, 'normally we operate on a tight 467 budget, and the availability of finances is a key issue..... also employees prefer to be compensated in other ways.' What appeared to be more valued among employees were informal recognitions afforded by management and/or peers when they engage in innovative behaviors. Receiving sincere thanks or being recognized by management for efforts undertaken were deemed to be valuable reinforcers of 471 entrepreneurial actions. As GoodSell's employee mentioned, 'to be recognized for a job well done is 472 more than enough. It's not [just about] money but knowing you are appreciated.'

473 Additionally, promotion was identified as a highly valued reinforcer of entrepreneurial actions by 474 various respondents across the case firms. For example, InfoComm regularly offered internal promotions 475 to aspiring and innovative employees. As such, the current crop of managers all rose to their current 476 positions as a result of this policy. Furthermore, interviews with respondents revealed that promotion 477 provided a sense of a job security in a country where there were generally limited opportunities and tough 
479 closer relations with the firms’ owners and senior managers, something that was noted as being highly

480 valued in the Kenyan culture. In African societies, small firms operate in a system of mutually benefiting

481 reciprocities (Khavul, Bruton, and Wood 2009) and having strong social ties between employees and

482 employer eventually leads to the development of trust and other benefits (Khavul, et al. 2009), which the

483 evidence here suggests may include entrepreneurship.

484 In considering the above evidence, we find that the current conceptualizations of CE regarding 485 rewards and reinforcement did not fit well with the experience of emerging economy SMEs. Accordingly, 486 our scoring of rewards and reinforcement was mostly low across our case firms (see Figure 1). More 487 specifically, our findings suggest that resource considerations and uncertainties in the institutional 488 environment can influence the capacity of SMEs in emerging economies to design and ultimately reward 489 their employees for CE related activities (Jackson et al. 2008). Additionally, our findings also allude to a 490 distinction between the type of entrepreneurial rewards valued by employees in emerging economy SMEs 491 and those from Western larger firms. Given the uncertain environmental conditions in societies like 492 Kenya, where collective responsibilities towards kith and kin are very real (Nyambegera, Sparrow and 493 Daniels 2000), predictable rewards and incentives such as promotion and job security are preferred 494 amongst our case firm respondents. This stands in stark contrast to the earlier findings from larger firms, 495 where the value of promotion as a reward has been discredited (Carrier 1996)

\section{Work discretion/autonomy}

Prior research suggests that entrepreneurial outcomes arise from those that have latitude and 498 freedom from excessive oversight, enjoy some level of responsibility, and are not excessively penalized 499 for failure from experimentation (Hornsby et al. 2002). However, our data suggested that respondents in 500 our case firms generally had little opportunity to exercise individual work discretion because of cultural 501 expectations and the general work environment. Our case analysis indicated that management's 502 expectations of their own behaviors in the workplace are central to how work discretion was ultimately 503 viewed and afforded to their subordinates. Amongst our case firms, there was a strong belief and 
expectation among senior management in particular that they should take 'the lead' and 'be involved in every aspect of the firm activities'. In this vein, the founder of GoodSell expressed his reservations about giving 'too many opportunities to make decisions to employees' because he preferred to be actively involved in all of the firm's decision-making processes, particularly when it came to allocation and use of financial resources. Most of those interviewed also shared similar opinions, as SafePack’s Engineering 509 Director stated, 'decisions are largely top down and I have to follow the rules and budget I am given.' 510 Although some leverage was afforded to staff in terms of implementing ideas, this privilege was found to 511 be largely afforded to a special few who had strong ethnic and familial ties with the owners and/or senior 512 management: 'In this firm (SafePack), if you are close to the top people, they listen to you, they let you 513 make decisions. But you have to earn your spot in that circle.' Informal discussions and observations with respondents further revealed that while some preferred to have empowerment in their jobs, many still preferred to defer decision making to those higher up the hierarchy. Interestingly, such preferences continued to prevail even though some of the 517 firms (KeTours, InfoComm and GoodSell) moved towards decentralized organizational structures and 518 changes to work structures and roles, designed to specifically increase individual autonomy. Our finding 519 here is consistent with existing studies that reveal how collectivist societies like Kenya are akin to 520 authoritarianism and in-group authority relationships (Kemmelmeier et al. 2003). Our data also indicated 521 that deference to authority not only influenced individual employees’ interest in engaging in innovative or 522 entrepreneurial activity, but also the case firms' ability to quickly identify and exploit entrepreneurial 523 opportunities in the market. For example, GoodSell had missed out on several opportunities to expand its 524 business domain into new areas, as the Sales Director felt it necessary to always confer with the founder 525 first.

With regards to tolerance of failure, few if any of the case firms were willing to tolerate failure 527 from entrepreneurial experimentation. In fact, the case evidence indicated that attitude towards tolerating 528 failure was strongly linked to very stringent cost-benefit or financial control systems embedded within 529 each firm. There was a general attitude among the case firms that failure is unacceptable and could lead to 
531 that, 'only the best ideas are supported because if you fail, you let a lot of people down.' Moreover, 532 because resources are limited, access to financial resources was reserved for only those projects that are 533 likely to succeed. Hence, there is little opportunity for experimentation and testing of new ideas.

534 Our findings here are line with those of van Wyk and Adonisi (2012) regarding the negative 535 effects of authoritarianism on CE in the African context. Our case evidence suggests a nuanced pattern of 536 work discretion wherein top-down decision making and stringent organizational processes limited the 537 individuals' entrepreneurial behaviors necessary for successful CE. From these findings, it seems that few

538 firms offer their key employees opportunities for work discretion and those that do seem to implant a very 539 stringent cost-benefit or financial control system. Such financial control systems are noted to have an 540 aggravating effect on CE (Barringer and Bluedorn 1999). In considering the above evidence, we note that 541 the experiences of emerging economy SMEs with respect to affording employees work discretion for 542 entrepreneurial initiatives did not align well with our current conceptualization of the antecedent. Thus we 543 found that most of our case firms displayed mostly low levels of work discretion (see Figure 1). 544 Moreover, our findings regarding how financial controls and cultural attitudes towards hierarchal 545 relationships hamper the case firms' CE, builds on to existing theoretical expectations.

546 Time availability

547 In contrast to the role that the CE literature assigns to time availability, our case firms provided 548 little slack time outside of non-essential tasks (Hornsby et al. 2002). When asked during the interviews 549 whether they had time to work on entrepreneurial ideas in the last three months, almost all our 550 respondents voiced a strong desire to have more 'free time' to do so. When asked why their time for 551 entrepreneurial efforts was limited, our respondents identified a number of salient factors both within and 552 outside of their respective organizations that influenced their time availability. Externally, we note that 553 our case firms found themselves competing in highly dynamic and competitive environments. For 554 instance, KeTours operates in the highly emergent tourism sector in Kenya, and faces relentless 
competition from both local and increasingly overseas competitors. Similarly both SafePack and InfoComm are constantly striving to establish themselves in their respective markets.

In such situations, we found respondents to be particularly focused on salient tasks such as meeting sales targets, building reputation and addressing customer needs as they were considered necessary for competing in such markets. As such 'slack time' for entrepreneurial initiatives was considered almost too valuable of a resource to be freely given. SafePack’s Training Coordinator claimed

561 that, 'in small and rapidly growing firm, time to work on new ideas to improve systems and process is 562 largely limited because very little time available, as we were often required to focus on more pressing 563 issues'. Furthermore, we also note that in the cases of KeTours and InfoComm, lack of technological 564 availability and sophistication in the Kenyan marketplace also increased managers and employees time 565 spent on such tasks.

Two main issues emerged that appeared to affect respondents' time availability for 567 entrepreneurial activity, both of which have received little attention in the existing literature. First, 568 amongst three of our four case firms (KeTours, SafePack and InfoComm), there was a strong push by 569 management to become ISO9000-certified in order to remain competitive in their markets. However both 570 the CEOs of SafePack and InfoComm acknowledged that the pursuit of effectiveness and efficiency 571 through the certification process came at the expense of organizational innovativeness. As the CEO of 572 SafePack explained, 'at first we were mostly geared towards trying to be the innovative leader in our 573 market place, but now, our focus is much more production planning and technology planning.' 574 Consequently such changes have also had a trickledown effect on employees' time availability for 575 entrepreneurial efforts. For instance at KeTours and InfoComm, managers now spend a considerable 576 amount of their time on routine tasks and the documentation of procedures and processes as opposed to 577 working on more entrepreneurial initiatives. As the Chief Information Officer of InfoComm explains, 578 'with all these new process coming into place, compliance is a major issue..... by and large my job is just 579 to make sure things run smoothly as possible.' 
581 firms, a notion supported by studies of SMEs (e.g., Alpkan et al. 2010). However, prior research has also 582 demonstrated that SMEs, particularly those from Africa, often face difficulty in acquiring the necessary 583 human capital resources, hence affecting their growth and development prospects (Smith and Watkins 584 2012). Our data indicated a similar story. Across the board, our firms found it difficult to recruit quality 585 human resource among Kenyan graduates. Particularly lacking were graduates or employees with 586 entrepreneurial skills and competencies necessary to work in such fast growing and dynamic firms. As a 587 result, managers often found themselves being highly involved in overseeing the actions of employees. 588 For instance, middle managers from both GoodSell and SafePack revealed that much of their time was 589 spent on monitoring the work of their subordinates as many of them did not possess the necessary skills to 590 complete their jobs sufficiently. SafePack's R\&D manager explained that, 'I need to keep track of what 591 my team is doing. And that keeps me busy most of the time.' In sum, our findings suggest that emerging economy SMEs experienced difficulties in providing slack time for entrepreneurial activities by important groups of people across the firm, in ways that has not been properly accounted for by the existing conceptualization of this antecedent. Our scoring of the 595 antecedent indicates low levels of time availability of entrepreneurial activities across the four case firms 596 (see Figure 1).

Prior research has suggested a cascading effect with respect to time availability and 598 organizational positioning (Hornsby et al. 2009). However, our evidence indicates that in emerging 599 economy SMEs, despite their organizational positions and titles, many of the employees’ job roles and 600 scopes still remain quite narrow. However, our findings do further highlight that a focus on efficiency and 601 multitasking can further undermine time availability for entrepreneurial initiatives and a further degree of 602 interaction among elements of the internal environment put in place by top managers which is hitherto not 603 well understood in the CE literature (Hornsby et al. 2009). Secondly, our findings highlight the 604 aggravating effects of skill deficiencies among human capital resources with respect to facilitating CE 605 through their effect on time availability and its subsequent use (Hayton and Kelly 2006). Hence we 
606

607

608

609

610

611

612

613

614

615 Furthermore, our in-depth interviews revealed that such structural changes were also accompanied by

616

617

618

619

620

621

622

623

624 boundaries antecedent (Hornsby et al. 2013a), our case findings shed new insights as to how

625 organizational boundaries facilitate CE. In particular, our case analysis highlights the importance of top

626 management in creating arenas for promoting interpersonal relationship and trust among employees,

627 teams and departments, which subsequently promote idea generation and ultimately CE. For example, at

628 InfoComm and GoodSell, senior management facilitated the coming together of individuals and teams in

629 order to formulate new ideas or devise new projects. However, in both these firms, such actions and

630 efforts were not undertaken as 'first moves' or initiatives but instead were reactions to disputes. The lead

631 Software Engineer of InfoComm pointed out that teams are constantly quarrelling over technical details 
632 of their projects or ideas. This inhibits their proactive behaviors (e.g., looking for new solutions to the

633 problem). Similarly, KeTours' top management believes that it is their responsibility to overcome such

634 issues. As the Managing Director pointed out, 'when managers disagree I sit down with them to discuss

635 the pros and cons of their ideas and the sources of their concern. I find that this helps them to come up

636 with a common or more practical solution'. Hence, by acting as relationship brokers, top management

637 promotes interconnectedness among individuals and departments and this drives information sharing

638 which would otherwise be suppressed.

639 This view of how organizational boundaries come to play a role in CE is contextually very

640 different from its conceptualization in the literature as that of boundary spanning individuals. Rather,

641 boundaries are broken when top managers broker and facilitate relationships and new solutions among

642 otherwise quarreling team members or departments/divisions. This evidence also implies that constructive

643 conflict may play a relevant role in CE within the emerging economy SME context. Again, this is

644 hitherto not considered in the literature on CE. Thus, we add important insights into the current

645 conceptualization of organizational boundaries as an antecedent of CE. Our case evidence suggests that

646 top managers may assume the role of intrapreneurs themselves and purposefully act as builders of

647 networks or human interactions within their businesses, subsequently promoting CE through collective

648 entrepreneurship (Toledano, Urbano and Bernadich 2010). This may be especially important in the

649 context of SMEs and emerging economy firms, because such close working relationships between

650 employees and management hold the potential to enhance levels of trust and communication between and

651 among these groups. Secondly, by shaping organizational boundaries, top managers' active involvement

652 in bringing people together regularly might be one way to compensate for the otherwise limited

653 availability of resource and time for entrepreneurial actions.

\section{DISCUSSION AND CONTRIBUTIONS}

655 In response to recent calls for research on what enables CE in emerging economy SMEs

656 (Hornsby et al. 2013b; Hoskisson et al. 2000; Phan et al. 2009) and comparable calls to action to examine 

and Wright, 2011), this paper makes three theoretical, empirical and methodological contributions.

As a theoretical contribution, our study shows that a supportive internal organizational environment is as important for CE in SMEs in emerging economies as it is for their established Western counterparts, but, and more importantly, our findings reveals that the manifestation of this internal organizational environment is very different to the status quo presented in current theory. This provides compelling evidence to support Zahra and Wright's (2011) claim that the reduction of context to a simple control variable masks fundamental knowledge that is crucial to the advancement of theory across the that some of the established antecedents do replicate at the SME level and in the emerging economy context. But this is not the case. Although our case firms provided top management support and manipulated organizational boundaries to promote CE, they did so in ways that differed from treatments reported in the literature so far (e.g., Hornsby et al. 2002, 2013a, 2014). They were executed differently

671 and contextualized to the circumstances of emerging economy SMEs. For top management support, 672 formalized support mechanisms for allocating financial and non-financial resources towards 673 entrepreneurial efforts were limited and managers conservatively and cautiously managed their firms' 674 resource stocks. Instead, managers oriented the allocation of resources towards entrepreneurial projects by 675 adopting a much longer term perspective and increasing the due diligence behind entrepreneurial 676 initiatives. Interestingly, these results are not consistent with studies of other emerging economies. Sebora 677 et al. (2010) found support for the more traditional characterization of top management support in Thai 678 SMEs, which suggests that regional institutional differences are more important than economic ones to 679 understand the motivation of CE. These results also differ from studies of SMEs in Western economies. Frank et al. (2010) reported that in difficult, dynamic environments, for firm entrepreneurial behavior to take place productively, high access to financial capital is needed. Yet our Kenyan SMEs were vibrant and entrepreneurial despite 

non-managerial employees, top managers showed a willingness to rapidly bring the best ideas of their other managerial and non-managerial employees to the attention of owners. Our findings extend those of

686 Castrogiovanni et al. (2011). The personal relationships top managers hold with their employees is an 687 important form of non-resource support that motivates CE among our emerging economy service sector 688 SMEs. This shows a need for models of, and judgments about, CE to be far more culturally contextually 689 sensitive. Our findings enrich a context-sensitive analysis of the antecedents of CE (de Villiers-Scheepers 690 2012; Hornsby et al. 2013b; Phan et al. 2009; Zellweger and Sieger 2012) by providing a fine-grained 691 representation of top management support as an enabler of CE in emerging economy SMEs. raise important questions about how entrepreneurship in emerging economy SMEs might come about. We found support for this antecedent but its execution was very different to expectations in the established 695 literature (e.g., Hornsby et al. 2002, 2013a, 2014), and it appears to be quite vulnerable to context sensitivity. Historically, the notion of organizational boundaries has been presented as one of 697 entrepreneurial individuals spanning organizational boundaries to link disparate parts of the firm together, 698 sharing knowledge and enabling novel knowledge to emerge and new innovative ideas and initiatives to 699 germinate. In our case firms, individuals, teams and departments across the firms exhibited regular 700 quarrelling and were brought together across boundaries by top managers acting as brokers and 701 negotiators to bring people together. Thus, the whole process of germinating dialogue and new solutions 702 to emerge was orchestrated heavily. So far, this problem has not surfaced in investigations of the 703 antecedents of CE, but our findings resonate with prior concerns that a strongly collectivist environment 704 may give rise to anti-entrepreneurship sentiment and group performance to suffer from dysfunctional 705 syndromes (Jackson et al. 2008; Morris et al. 1994). This is likely to be further exacerbated by the fact 706 that management philosophies in Kenya are dominated by sharp distinctions in status differences among 707 groups of employees across the firm (Kiggundu 1988). We contribute an extension to the present 
theoretical framework of CE antecedents by showing that boundary spanning behavior must be led by managers first, and not left to employees alone as advocated in current theory.

These observations can also be further understood when considering our findings about work discretion. Few opportunities for work discretion were granted outside of top management and top managers themselves sought hands on involvement in projects with employees, and particularly in decision-making. Taken with our observations about organizational boundaries, it is quite possible then that individuals and teams simply did not consider autonomously crossing boundaries viable because of the absence of, and some lack of desire for, absolute work discretion. Therefore, we enrich the body of theory for examining CE by demonstrating the value of institutional and cultural lenses to understand what enables CE in contexts for removed the traditional Western perspective. Individuals were not mindful to adopt work discretion even when provided by top manager, contradicting the emphasis placed on work discretion and autonomy in current theory (Hornsby et al. 2002; Lumpkin and Dess 1996) Theoretical development in the field of CE will need to rely on institutional theory and contextual analysis if we are to progress our knowledge about situationally-relevant antecedents and enablers.

Also apparent from our data were interactions among the antecedents of CE unforeseen in the existing literature. For example, offering work discretion is compromised by the existence of strong financial controls and stringent cost-benefit regimes while time availability is rare. Also, work discretion was rebalanced by top managers purposefully crossing organizational boundaries to resolve problems caused by quarrelling teams. This illustration paints a different image of the use of organizational boundaries as a means of stimulating CE by reducing information-seeking time, reducing costs, overcoming the limitations of time unavailability, and increasing confidence in top management support for entrepreneurial initiatives. Such complicated interactions have yet to be modelled in current frameworks of CE. These findings reveal that a black box between antecedent conditions and CE outcomes that is at least in part a function of emerging economy SMEs context.

As an empirical contribution, we observe that for employees, entrepreneurship within the context of the job and securing promotion coupled with a close relationship with supportive and active top 
managers sets the context for CE to take place, even in what might otherwise appear as unproductive conditions in more traditional contexts. For example, while employees were cognizant of how rewards were linked to their entrepreneurial efforts, promotion and non-financial rewards such as recognition for a 737 job done well were most valued, and employees respected the need for compliance behavior. Ideas of 738 compliance and deference are orthogonal to our knowledge of what entrepreneurship in SMEs requires, 739 and we add empirical evidence to a group of studies that collectively reveal the problems of deference to 740 authority (e.g., Beugré and Offodile 2001; Jackson et al. 2008; Kamoche 2011; van Wyk and Adonisi 741 2012). In our case firms, that deference to authority even overruled a cultural expectation of obedience of managerial instructions. Thus, even when granted autonomy and asked to engage in entrepreneurship, deference to authority suppressed them from taking up of those initiatives. This new empirical contribution raises further questions about the theoretical and practical accuracy of current frameworks. find that rewards for entrepreneurial actions can be undermined by signals caused by the outcomes of reward systems (e.g., promotions encouraging job security diminished a sense of need to take entrepreneurial risks). Our data suggested that individuals within the case firms were analytical and reflective in deciding how they behaved in their work. They tended to be less spontaneous in their behavior and less willing to take risks unless it protected their job, and this behavior was hardened by the tendency among the firms to use rewards/reinforcements systems that emphasized job security. Studies 752 have long been of the view that Kenyan employees assign the highest importance to security needs (Blunt and Jones 1986) but we observe empirically that the reticence to entrepreneurship this causes can be overcome by promotion and recognition from managers and peers being provided as rewards for entrepreneurship. Doing so converts the desire for security away from one of restrained behavior to one of entrepreneurship when aligned to such non-financial rewards. Considering the role of SMEs in raising

757 quality of life in emerging economies, these findings lend support to Bruton, Alsthrom and Si’s (2015) 758 call for poverty alleviating mechanisms that go beyond subsistence entrepreneurship. The study 759 highlights the role of institutional actions (George, Nicholson, Corbishley \& Bansal, 2014) and conditions 
necessary for CE. By improving internal conditions, employees are more likely to simply work to survive and in fact are more willing innovate and create new opportunities for growth. In more practical terms we see an emerging connection to improvements in the way firms do business and their potential effect on improving living standards in developing economies.

Finally, we make a small methodological contribution. In the spirit of Zahra et al. (1999), the use of a qualitative methodology helped us generate a much better understanding of the 'how' and 'why' of CE in the context of emerging economy SMEs, where knowledge (both theoretical and empirical) remains thin. Using a qualitative methodology over the more traditional quantitative approach in assessing the internal antecedents for $\mathrm{CE}$ allows us to overcome problems associated with singlerespondent research and the de-contextualization of CE in prior studies. Studies wishing to examine wellestablished concepts and instruments in different contexts such as emerging economies can use our protocols to develop more context-sensitive treatments of CE in future.

Drawing this discussion together, we offer a revised and extended theoretical framework of the antecedents of CE that can serve small business researchers interested in advancing the field towards a greater appreciation of CE in emerging economies and service sector SMEs therein. This extended theoretical framework is illustrated in Figure 2. Our findings speak to managers and policy-makers who work closely with emerging economy SMEs. Such individuals need to be cautious of adopting and recommending CE frameworks and practices developed in studies of firms within developed economies, and should be more mindful of how entrepreneurial processes and practices may be influenced by context. Our work offers a basis to resolve this problem.

\section{INSERT FIGURE 2 ABOUT HERE}

\section{LIMITATIONS AND FUTURE RESEARCH}

Our study is not without limitations. First, adopting a qualitative methodology constrains the generalizability of our findings to the theoretical and analytical alone. Our selection of cases sits within 
the Kenyan service sector SMEs. Our observations might be less relevant to non-service sector SMEs, 787 larger more established firms, and firms from different institutional contexts. However, we note that we 788 did not seek to generalize our findings to these audiences. Instead, we sought to give rich contextualized 789 insights into how the specific antecedents for CE are manifested in emerging economy SMEs.

Second, our study is appropriately qualitative in nature given inconsistencies and questions we 791 raised and reported in our literature review on the relevance of the five repeatedly-emphasized 792 antecedents of $\mathrm{CE}$ to non-traditional contexts. We also appropriately noted our concern that the 793 dominance of quantitative methodologies in the research into the antecedents of CE has ushered in a de794 contextualization of the antecedents of CE that is clearly problematic based on our qualitative findings. 795 Still, a mixed methods approach could have enabled us to provide a larger set of data from which to study 796 the emerging relationships drawn from our qualitative findings. Future research may wish to adopt such 797 an approach to studying CE in non-traditional contexts.

Finally, our study focused only on a direct set of established internal antecedents to CE and searched for anomalies and (in)consistencies within that remit. Studies with a broader scope then ours may consider external and environmental antecedent as well (Frank et al. 2010). Such an approach has the potential to offer small business researchers a theoretical framework in advancing the field towards greater appreciation of the antecedents of CE in non-traditional contexts.

804 body of knowledge on CE among emerging economy firms (Hornsby et al. 2013a) remains a concern. 805 Future research may do well to extend this study into other emerging economies and diverse 806 organizational contexts such as larger established firms. Second, our findings suggest that the antecedents 807 of CE established in the literature are subject to context sensitivity in complex ways. Such a theoretical 808 omission represents a problem in present treatments of CE based on our findings. While our paper offers a 809 contribution in carving out deviations from the CEAI model, it implies that a set of hitherto unforeseen 810 and undiscovered mediators and moderators acting on how a firm might organize effectively for CE likely 811 exist. Appreciating how CE is achieved and practiced among emerging economy firms affords scholars 
812 the opportunity to develop better theories and conceptual models of CE and managers to arrive at better 813 customized prescriptions to improve the competitiveness of their firms.

814 Finally, we urge future research studies to consider how the institutional environment influences 815 the adoption of CE initiatives among emerging economy firms. Earlier, Gómez-Haro et al. (2011) drew 816 scholarly attention to the important influence of both the formal and informal environments on firm-level 817 entrepreneurial activities. We urge future researchers to consider how the external environmental 818 (whether formal or informal) may influence the adoption and implementation of the internal antecedents

819 for CE. Such an approach offers a premise for the development of theoretical frameworks that can further 820 serve small business researchers who are interested in advancing the field towards a greater appreciation 821 of the antecedents of CE efforts and enlarge our understanding of how SMEs can become more 822 competitive in emerging economies

\section{CONCLUSION}

The central question guiding this study was whether the current conceptualization of the five 825 antecedents of a supportive internal environment for CE remains applicable and relevant in the context of

826 SMEs in an emerging economy. Drawing on the Kenyan service sector SMEs as our empirical starting 827 point, our findings reveal that institutional and cultural variations as well as context-specific features 828 within the Kenyan service sector SME landscape and workplace shaped how CE needed to be organized 829 in these firms. We contribute both theoretically and empirically to the existing literature by suggesting 830 that the organization of Kenyan SMEs' internal environments for CE is much more nuanced, interactive, 831 and complex than currently presented in Western treatments and studies. The findings contained within 832 this study offer an insightful basis on which to further examine how context impinges on entrepreneurial 833 actions in firms outside of the traditional Western context and extend the theoretical framework of the 834 antecedents of CE. 
Table 1

Profiles of Case Firms

\begin{tabular}{|c|c|c|c|c|}
\hline & KeTours & GoodSell & SafePack & InfoComm \\
\hline Year of inception & 2004 & 1988 & 1995 & 2005 \\
\hline $\begin{array}{l}\text { Number of CE } \\
\text { related initiatives } \\
\text { implanted since } \\
\text { inception }\end{array}$ & 4 & 7 & 3 & 3 \\
\hline $\begin{array}{l}\text { Example of } \mathrm{CE} \\
\text { activity in case firms }\end{array}$ & $\begin{array}{l}\text { External corporate venturing, KeTours } \\
\text { saw an opportunity to take advantage of } \\
\text { growing demand in adventure tourism } \\
\text { in Kenya and Africa. CEO along with } \\
\text { VP created a new firm specifically } \\
\text { dedicated to developing new products } \\
\text { for these markets. Later new company } \\
\text { became more closely integrated into } \\
\text { KeTours online booking platforms }\end{array}$ & $\begin{array}{l}\text { Strategic renewal in the form of } \\
\text { domain re-definition. Since 1995, } \\
\text { GoodSell has used its financial } \\
\text { resources and market knowledge to } \\
\text { enter in new allied business markets. } \\
\text { Later in 2003, GoodSell further } \\
\text { increased its hold in the markets by } \\
\text { developing a sales portal. It was also } \\
\text { one of the first firms in Kenya to offer } \\
\text { online financing and credit options for } \\
\text { customers. }\end{array}$ & $\begin{array}{l}\text { Product and process innovation. After } \\
\text { years of distributing imported safety } \\
\text { products for the oil and gas industry, } \\
\text { SafePack began developing new } \\
\text { customized products for the relevant } \\
\text { markets. In } 2007 \text { Safe pack made the bold } \\
\text { move to enter into markets (government } \\
\text { clients and personal users) by creating a } \\
\text { spin-off venture to deal with new markets. }\end{array}$ & $\begin{array}{l}\text { Since } 2007 \text { InfoComm has embarked on } \\
\text { a process of rapid new product } \\
\text { development. Additionally InfoComm } \\
\text { has expanded its core business from } \\
\text { software development into providing } \\
\text { customers with a total care and } \\
\text { maintenance package, through creation } \\
\text { of a new internal operating division. }\end{array}$ \\
\hline Nature of Services & Tourism/Travel Services & Retail Sales (Online) & $\begin{array}{l}\text { Health and Safety Equipment and } \\
\text { Distribution Provider }\end{array}$ & Information Technology Solutions \\
\hline $\begin{array}{l}\text { Number of } \\
\text { Interviewees }\end{array}$ & $\begin{array}{l}\text { Founder, Managing Director, } \\
\text { Operations and Planning Manager, } \\
\text { Sales and Marketing Manager }\end{array}$ & $\begin{array}{l}\text { Founder, Sales Director, Online } \\
\text { Projects manager, Marketing and } \\
\text { Operations Manager, Employee }\end{array}$ & $\begin{array}{l}\text { CEO, Engineering Director, R\&D } \\
\text { manager, Training Coordinator }\end{array}$ & $\begin{array}{l}\text { Managing Director, Chief Information } \\
\text { Officer, New Projects Manager, } \\
\text { Software Engineer }\end{array}$ \\
\hline $\begin{array}{l}\text { Total Number of } \\
\text { Employees }\end{array}$ & 165 & 80 & 42 & 24 \\
\hline $\begin{array}{l}\text { Annual Turnover } \\
\text { (\$USD) }\end{array}$ & $11.43 \mathrm{~m}$ & $3.1 \mathrm{~m}$ & $0.83 \mathrm{~m}$ & $2.1 \mathrm{~m}$ \\
\hline $\begin{array}{l}\text { Business History and } \\
\text { CE Activities }\end{array}$ & $\begin{array}{l}\text { Initially started as small regional airline. } \\
\text { Rapid expansion over the past } 6 \text { years, } \\
\text { with a number of innovative business } \\
\text { practices developed internally. First } \\
\text { regional airline to use internet bookings } \\
\text { and payment system. More recent } \\
\text { innovative activities have been based } \\
\text { around developing high quality } \\
\text { products, specialized tours }\end{array}$ & $\begin{array}{l}\text { Started as a small real estate firm in } \\
\text { the late } 1980 \text { 's. Company has grown } \\
\text { rapidly since then and branched out } \\
\text { into a number of allied areas, such as } \\
\text { property management and online } \\
\text { retailing. Recently new innovative } \\
\text { practices have emerged which has } \\
\text { enabled the company to develop its } \\
\text { own online portal, and introduction of } \\
\text { financing options for customers and } \\
\text { making them the premier online } \\
\text { trading company in Kenya. }\end{array}$ & $\begin{array}{l}\text { The company was mainly founded from } \\
\text { the efforts of its owner, who previously } \\
\text { was working for large oil MNC in Kenya. } \\
\text { The main activity was based around } \\
\text { providing health and safety equipment to } \\
\text { oil and gas companies. More recently as } \\
\text { result of CE activities, company has } \\
\text { designed their own products and expanded } \\
\text { to develop and deliver their own OHS } \\
\text { programs for corporate and government } \\
\text { clients. The company has also moved into } \\
\text { sales and distribution of such product }\end{array}$ & $\begin{array}{l}\text { Business originally founded to provide } \\
\text { IT solutions to existing companies. } \\
\text { Since } 2007 \text { firm has engaged in a } \\
\text { number of new projects based on } \\
\text { developing and commercializing new } \\
\text { software specifically for the East } \\
\text { African market. Original business line } \\
\text { also expanded designed to offer } \\
\text { permanent assistance for clients. Latest } \\
\text { CE project involve rebranding and } \\
\text { change to organizational structure which } \\
\text { resulted in winning lucrative } \\
\text { government contract. }\end{array}$ \\
\hline
\end{tabular}


Table 2

Cross case analysis of the internal antecedents

\begin{tabular}{|c|c|c|c|c|}
\hline Antecedents & KeTours & GoodSell & SafePack & InfoComm \\
\hline $\begin{array}{l}\text { Top Management } \\
\text { Support }\end{array}$ & $\begin{array}{l}\text { Championing of ideas \& bringing } \\
\text { together people; Strong } \\
\text { entrepreneurial spirit; moderate } \\
\text { resource commitment }\end{array}$ & $\begin{array}{l}\text { Championing of ideas and } \\
\text { bringing people together; } \\
\text { Low resource commitment }\end{array}$ & $\begin{array}{l}\text { Championing of ideas; Open door } \\
\text { policy to employees; low resource } \\
\text { commitment }\end{array}$ & $\begin{array}{l}\text { Strong championing of ideas \& bringing } \\
\text { together people; strong entrepreneurial } \\
\text { spirit; Open door policy to employees; } \\
\text { Financial support is available. }\end{array}$ \\
\hline $\begin{array}{l}\text { Rewards/re- } \\
\text { enforcements }\end{array}$ & $\begin{array}{l}\text { Limited performance review } \\
\text { system, focused on easy to asses } \\
\text { goals, limited recognition of } \\
\text { individual entrepreneurial efforts } \\
\text { Rewards mostly non-financial, } \\
\text { e.g. informal recognition }\end{array}$ & $\begin{array}{l}\text { ad-hoc performance review } \\
\text { systems, no specific } \\
\text { recognition of entrepreneurial } \\
\text { efforts } \\
\text { Rewards mostly non- } \\
\text { financial, e.g. informal } \\
\text { recognition, job security }\end{array}$ & $\begin{array}{l}\text { Informal and ad-hoc performance } \\
\text { review systems, ambiguous } \\
\text { assessment and recognition of } \\
\text { entrepreneurial efforts } \\
\text { Rewards mostly non-financial, } \\
\text { internal promotion, benefits }\end{array}$ & $\begin{array}{l}\text { Formalised performance review system, } \\
\text { ambiguous or inconsistent recognition of } \\
\text { individual entrepreneurial efforts } \\
\text { Some financial rewards, also non- } \\
\text { financial rewards, e.g. informal } \\
\text { recognition, internal promotion }\end{array}$ \\
\hline $\begin{array}{l}\text { Work } \\
\text { Discretion/Autonomy }\end{array}$ & $\begin{array}{l}\text { Low tolerance for failure; strict } \\
\text { operating procedures with } \\
\text { regards to processes; moderate } \\
\text { delegation of authority; } \\
\text { employees prefer to defer to } \\
\text { authority }\end{array}$ & $\begin{array}{l}\text { Low tolerance for failure; } \\
\text { top-down decision making; } \\
\text { strict financial controls; } \\
\text { employees prefer to defer to } \\
\text { authority }\end{array}$ & $\begin{array}{l}\text { Low tolerance for failure; top-down } \\
\text { decision making; strict financial } \\
\text { controls; employees prefer to defer to } \\
\text { authority }\end{array}$ & $\begin{array}{l}\text { Moderate tolerance for failure; top-down } \\
\text { decision making; Moderate financial } \\
\text { controls; employees prefer to defer to } \\
\text { authority }\end{array}$ \\
\hline Time Availability & $\begin{array}{l}\text { Limited slack time availability } \\
\text { due to unstructured job roles and } \\
\text { high market pressure; pursuit of } \\
\text { ISO certification increased } \\
\text { administrative workload of } \\
\text { managers }\end{array}$ & $\begin{array}{l}\text { Limited slack time } \\
\text { availability due to high } \\
\text { workload; high need to } \\
\text { monitor staff activity }\end{array}$ & $\begin{array}{l}\text { Limited slack time availability due to } \\
\text { unstructured job roles and high } \\
\text { market pressure; high need t o } \\
\text { monitor staff activity; pursuit of ISO } \\
\text { certification increased administrative } \\
\text { workload of managers }\end{array}$ & $\begin{array}{l}\text { Some slack time given to employees to } \\
\text { pursue entrepreneurial ideas; high } \\
\text { pressure to remain competitive in the } \\
\text { market; pursuit of ISO certification } \\
\text { increased administrative workload of } \\
\text { managers }\end{array}$ \\
\hline $\begin{array}{l}\text { Organizational } \\
\text { Boundaries }\end{array}$ & $\begin{array}{l}\text { Flat organizational structure } \\
\text { actively encouraging teamwork; } \\
\text { Relationship brokering by top } \\
\text { management; Organizational } \\
\text { learning is encouraged }\end{array}$ & $\begin{array}{l}\text { Flat organizational structure } \\
\text { actively encouraging } \\
\text { teamwork; Relationship } \\
\text { brokering by top management }\end{array}$ & $\begin{array}{l}\text { Some level of team work is } \\
\text { encouraged; Monthly review system } \\
\text { for innovative ideas in place }\end{array}$ & $\begin{array}{l}\text { Flat organizational structure actively } \\
\text { encouraging teamwork; Knowledge } \\
\text { management and learning systems are in } \\
\text { place; Relationship brokering by top } \\
\text { management; Idea generation system in } \\
\text { place }\end{array}$ \\
\hline
\end{tabular}


Figure 1

CEAI Profile of Cases

\begin{tabular}{|c|l|c|c|c|}
\hline \multicolumn{2}{|c|}{ KeTours } & \multicolumn{3}{c|}{ Level of Dimension } \\
\cline { 3 - 5 } \multicolumn{2}{|c|}{} & Low & Medium & High \\
\hline \multirow{3}{*}{} & top management support & & & \\
\cline { 2 - 5 } & rewards/compensation & i & & \\
\cline { 2 - 5 } & work discretion & I & & \\
\cline { 2 - 5 } & time availability & L- & & \\
\cline { 2 - 5 } & organizational & & & \\
\hline
\end{tabular}

\begin{tabular}{|c|c|c|c|c|}
\hline \multicolumn{2}{|r|}{ GoodSell } & \multicolumn{3}{|c|}{ Level of Dimension } \\
\hline & & Low & Medium & High \\
\hline \multirow{5}{*}{ 预.气气 } & top management support & & - - - & \\
\hline & rewards/compensation & & & \\
\hline & work discretion & 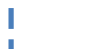 & & \\
\hline & time availability & L & & \\
\hline & $\begin{array}{l}\text { organizational } \\
\text { boundaries }\end{array}$ & & -------1 & $---n$ \\
\hline
\end{tabular}

\begin{tabular}{|c|l|c|c|c|}
\hline \multicolumn{2}{|c|}{ SafePack } & \multicolumn{3}{c|}{ Level of Dimension } \\
\cline { 3 - 5 } \multicolumn{2}{|c|}{} & Low & Medium & High \\
\hline \multirow{3}{*}{} & top management support & & & \\
\cline { 2 - 5 } & rewards/compensation & i & & \\
\cline { 2 - 5 } & work discretion & & & \\
\cline { 2 - 5 } & time availability & L & & \\
\cline { 2 - 5 } & $\begin{array}{l}\text { organizational } \\
\text { boundaries }\end{array}$ & & & \\
\hline
\end{tabular}

\begin{tabular}{|c|l|l|l|l|}
\hline \multicolumn{2}{|c|}{ InfoComm } & \multicolumn{3}{c|}{ Level of Dimension } \\
\cline { 3 - 5 } \multicolumn{2}{|c|}{} & Low & Medium & High \\
\hline \multirow{3}{*}{} & top management support & & & \\
\cline { 2 - 5 } & rewards/compensation & & & \\
\cline { 2 - 5 } & work discretion & & \\
\cline { 2 - 5 } & time availability & & \\
\cline { 2 - 5 } & $\begin{array}{l}\text { organizational } \\
\text { boundaries }\end{array}$ & & & \\
\hline
\end{tabular}


Figure 2

Theoretical framework of factors relevant to CE in emerging economy SMEs

Top management support:

a. Resource allocation

b. Non-resource support

c. Long-term horizon
Mixed influence as controlled by greater due diligence to mitigate resource liabilities (SME context)
Organizational boundary spanning and brokering of internal relationships among employees by top managers
Supportive (increases information sharing and mitigates quarrelling

Non-financial rewards

a. Promotion

Internal environment for $\mathrm{CE}$ in emerging economy servicesector SMEs

b. Recognition by managers and peers

Institutional pressure for compliance behaviour:

a. Reduced time availability

b. Deference to authority

c. Factors a and b potentially corrected by contextual work discretion
Mixed influence as reduced time availability and deference to authority suppress entrepreneurship but combated by contextual work discretion (emerging economy context)

Top management support might further mitigate problems of deference to authority in time 


\section{REFERENCES}

Ahlstrom, D., and G. Bruton (2010). 'Rapid institutional shifts and the co-evolution of entrepreneurial firms in transition economies,' Entrepreneurship Theory \& Practice, 34(3), 531-54.

Alpkan, L., C. Bulut, G. Gunday, G. Ulusoy, and K. Kilic (2010). 'Organizational support for intrapreneurship and its interaction with human capital to enhance innovative performance,' Management Decision, 48(5), 732-55.

Balistreri, E. J., T. Rutherford, and D. Tarr (2009). 'Modeling services liberalization: The case of Kenya', Economic Modelling, 26(3), 668-679.

Bateson, J.E.G (1992). Managing Services Marketing: Text and Readings (2nd ed). Orlando, FL: Dryden.

Barringer, B., and A. Bluedorn, C (1999). 'The relationship between corporate entrepreneurship and strategic management', Strategic Management Journal, 20(5), 421-444.

Beugré, C., and O. Offodile (2001). 'Managing for organizational effectiveness in sub-Saharan Africa: a culture-fit model', International Journal of Human Resource Management, 12(4), 535-550.

Blunt, P., and M. Jones (1992). Managing organizations in Africa. Berlin: Walter de Gruyter.

Bowen, M., and M. Mureithi (2009). 'Management of Business challenges among smalll \& Micro enterprises in Nairobi-Kenya', KCA. Journal of Business Management, 2(1), 23-39.

Bradley, S. W., H. Aldrich, D. A. Shepherd, and J. Wiklund (2011). 'Resources, environmental change, and survival: Asymmetric paths of young independent and subsidiary organizations,' Strategic Management Journal, 32(5), 486-509.

Bruton, G. D., D. Ahlstrom, and H. Li (2010). 'Institutional theory and entrepreneurship: Where are we now and where do we need to move in the future?' Entrepreneurship Theory and Practice, 34(3), 421440.

Bruton, G. D., Ahlstrom, D.,and S.Si (2015). 'Entrepreneurship, poverty, and Asia: Moving beyond subsistence entrepreneurship’. Asia Pacific Journal of Management, 32(1), 1-22.

Bruton, G. D., D. Ahlstrom, and K. Obloj (2008). 'Entrepreneurship in emerging economies: where are we today and where should the research go in the future,' Entrepreneurship Theory \& Practice, 32 (1), 1-14.

Carrier, C. (1996). 'Intrapreneurship in small businesses: An exploratory study', Entrepreneurship, Theory and Practice, 21(1), 5-20.

Castrogiovanni, G., D. Urbano, and J. Loras (2011). 'Linking corporate entrepreneurship and human resource management in SMEs,' International Journal of Manpower, 32(1), 34-47.

Christensen, K. S. (2005). 'Enabling intrapreneurship: the case of a knowledge-intensive industrial company,' European Journal of Innovation Management, 8(3), 305-322.

Covin, J. G., and M. Miles (2007). 'Strategic use of corporate venturing,' Entrepreneurship Theory and Practice, 31(2), 183-207.

de Villiers-Scheepers, M. (2012). 'Antecedents of strategic corporate entrepreneurship,' European Business Review, 24(5), 400-424.

Dess, G. G., G. T. Lumpkin, and J. E. McGee. (1999). 'Linking corporate entrepreneurship to strategy, structure, and process: Suggested research directions,' Entrepreneurship Theory \& Practice, 23, 85102.

Frank, H., A. Kessler., and M. Fink (2010). 'Entrepreneurial orientation and business performance-a replication study,' Schmalenbach Business Review, 62(2), 175-198.

Freel, M. S. (2005). 'Patterns of innovation and skills in small firms,' Technovation, 25(2), 123-134.

Fry, A. (1987). 'The post it note: An intrapreneurial success,' SAM Advanced Management Journal, 52(3), 4-9.

George, G., Rao-Nicholson, R., Corbishley, C., and R. Bansal (2015). 'Institutional entrepreneurship, governance, and poverty: Insights from emergency medical response services in India'. Asia Pacific Journal of Management, 32(1), 39-65. 
Gómez-Haro, S., J. Aragón-Correa, and E. Cordón-Pozo (2011). 'Differentiating the effects of the institutional environment on corporate entrepreneurship,' Management Decision, 49(9-10), 16771693.

Guth, W., and Ari Ginsberg (1990). 'Guest editors' introduction: corporate entrepreneurship,' Strategic Management Journal, 11(1), 5-15.

Hausman, A. (2005). 'Innovativeness among small businesses: Theory and propositions for future research,' Industrial Marketing Management, 34(8), 773-782.

Hayton, J.C., and D. Kelly (2006). 'A Competency-Based Framework for Promoting Corporate Entrepreneurship,' Human Resource Management Journal, 45(3), 407-427.

Hermelo, F. D., and R. Vassolo (2010). 'Institutional development and hypercompetition in emerging economies,’ Strategic Management Journal, 31(13), 1457-1473.

Hitt, M. A., R. D. Ireland., D. G. Sirmon., and C. A. Trahms (2011). 'Strategic entrepreneurship: creating value for individuals, organizations, and society,' Academy of Management Perspectives, 25(2), 57-75.

Holt, D.T., M. Rutherford, and G. Clohessy (2007). 'Corporate entrepreneurship: An empirical look at individual characteristics, context, and process,' Journal of Leadership \& Organizational Studies, 13(4), 40-54.

Hornsby, J. S., D. F. Kuratko., and R. V. Montagno (1999). 'Perception of internal factors for corporate entrepreneurship: A comparison of Canadian and US managers,' Entrepreneurship Theory and Practice, 24(2), 9-24.

Hornsby, J., D. Kuratko, and S. Zahra (2002). 'Middle managers' perception of the internal environment for corporate entrepreneurship: assessing a measurement scale,' Journal of Business Venturing, 17(3), 253-273.

Hornsby, J., D. Kuratko, D. Holt, and W. Wales (2013a). 'Assessing a measurement of organizational preparedness for corporate entrepreneurship,' Journal of Product Innovation Management, 30(5), 937955.

Hornsby, J., D. Kuratko, D. Shepherd, and J. Bott (2009). 'Managers' corporate entrepreneurial actions: Examining perception and position,’ Journal of Business Venturing, 24(3), 236-247.

Hornsby, J., I. Peña-Legazkue, and M. Guerrero (2013b). 'Guest editorial: the role of corporate entrepreneurship in the current organizational and economic landscape,' International Entrepreneurship and Management Journal, 9(3), 295-305.

Hoskisson, R., L. Eden, C. Lau, and M. Wright (2000). 'Strategy in emerging economies,' Academy of Management Journal, 43(3), 249-267.

Ireland, R., J. Covin, and D. Kuratko (2009). 'Conceptualizing corporate entrepreneurship strategy,' Entrepreneurship Theory and Practice, 33(1), 19-46.

Jackson T., A. Kenneth, and Y. Serap (2008). 'Untangling African indigenous management: Multiple influences on the success of SMEs in Kenya,' Journal of World Business, 43(4), 400-416.

Kamoche, K. (2011). 'Contemporary developments in the management of human resources in Africa,' Journal of World Business, 46(1), 1-4.

Kantur, D., and A. Iseri-Say (2013). 'Organizational context and firm-level entrepreneurship: a multiplecase analysis,' Journal of Organizational Change Management, 26(2), 305-325.

Kemmelmeier, M., E. Burnstein., K. Krumov., P. Genkova., C. Kanagawa., M. S. Hirshberg., H. E., G. Wieczorkowska., and K. Noels (2003). 'Individualism, collectivism, and authoritarianism in seven societies,' Journal of Cross-Cultural Psychology, 34(3), 304-322.

Khavul, S., G. D. Bruton, and E. Wood (2009). 'Informal family business in Africa,' Entrepreneurship Theory and Practice, 33(6), 1219-1238.

Kiggundu, M. (1988). 'Africa,' in Comparative Management: A Regional Review. Ed R. Nath. Cambridge: Ballinger.

Kraus, S. (2011). 'The role of entrepreneurial orientation in service firms: Empirical evidence from Austria', The Service Industries Journal, 35(5), 1-18.

Kuratko, D. F., Goldsby, M. G., \& Hornsby, J. S (2012). Innovation acceleration: Transforming organizational thinking. Upper Saddle River, NJ: Pearson/Prentice Hall. 
Kuratko, D. F., J. S. Hornsby, and J. G. Covin (2014). 'Diagnosing a firm's internal environment for corporate entrepreneurship,’ Business Horizons, 57(1), 37-47.

Kuratko, D. F., R.D. Ireland, J. G. Covin, and J. S. Hornsby (2005). 'A model of middle level managers' entrepreneurial behavior,' Entrepreneurship Theory and Practice, 29(6), 699-716.

Library of Congress (2007). 'Country Profile: Kenya,' Library of Congress - Federal Research Division, June 2007, http://lcweb2.loc.gov/frd/cs/profiles/Kenya.pdf. Retrieved April 27, 2015.

Lou, Y., and M. Junkunc, (2008). 'How private enterprises respond to government bureaucracy in emerging economies: the effects of entrepreneurial type and governance,' Strategic Entrepreneurship Journal, 2(3) 133-53.

Lovelock, C. H. (1994). Product plus: how product+ service. McGraw-Hill Companies.

Lumpkin, G., and G. Dess, (1996). 'Clarifying the entrepreneurial orientation construct and linking it to performance,' Academy of Management Review, 21(1), 135-157.

Matanda, M. (2012). 'Internationalization of established small manufacturers in a developing economy: A case study of Kenyan SMEs,' Thunderbird International Business Review, 54(4), 509-519.

Miller, D.J., M.J. Fern, and L.B. Cardinal, (2007). 'The use of knowledge for technological innovation within diversified firms,' Academy of Management Journal, 50(2), 307-326

Monsen, E., H. Patzelt., and T. Saxton (2010). 'Beyond Simple Utility: Incentive Design and Trade-Offs for Corporate Employee-Entrepreneurs,' Entrepreneurship Theory and Practice, 34(1), 105-130.

Morris, M. H., D. L. Davis., and J. W. Allen (1994). 'Fostering corporate entrepreneurship: Cross-cultural comparisons of the importance of individualism versus collectivism,' Journal of International Business Studies, 25(1), 65-89.

Morris, M., D. Kuratko, and J. Covin (2011). Corporate entrepreneurship and innovation, Cengage Learning; Boston.

Mwobobia, F. (2012). 'The Challenges Facing Small-Scale Women Entrepreneurs: A Case of Kenya,' International Journal of Business Administration, 3(2), 112-130

North, D. (1990). Institutions, Institutional Change and Economic Performance. In Political Economy of Institutions and Decisions, Cambridge; Cambridge University Press,

Nyambegera, S. M., P. Sparrow, and K. Daniels (2000). 'The impact of cultural value orientations on individual HRM preferences in developing countries: lessons from Kenyan organizations,' International Journal of Human Resource Management, 11(4), 639-663.

Nyanjom, O., and D. Ong'olo (2012). 'Erratic Development in Kenya: Questions from the East Asian Miracle,' Development Policy Review, 30(s1), s73-s99.

Patton, M. Q. (1990). Qualitative evaluation and research methods (2nd ed.). Newbury Park, CA: Sage Publications

Peltola, S. (2012). 'Can an old firm learn new tricks? A corporate entrepreneurship approach to organizational renewal,' Business Horizons, 55(1), 43-51.

Phan, P., M. Wright, D. Ucbasaran, and W. Tan (2009). 'Corporate entrepreneurship: current research and future directions,' Journal of Business Venturing, 24(3), 197-205.

Puffer, S., D. McCarthy, and M. Boisot (2010). 'Entrepreneurship in Russia and China: The impact of formal institutional voids,' Entrepreneurship Theory and Practice, 34(3), 441-467.

Rigtering, J.P. C., Kraus, S., Eggers, F., and Jensen, S. H (2014). 'A comparative analysis of the entrepreneurial orientation/growth relationship in service firms and manufacturing firms', The Service Industries Journal, 34(4), 275-294.

Ronge, E., L. Ndirangu, and H. Nyangito (2002). 'Review of government policies for the promotion of micro and small scale enterprises in Kenya (No. 20)', Kenya Institute for Public Policy Research and Analysis.

Rutherford, M. W., and D. T. Holt, (2007). 'Corporate entrepreneurship: An empirical look at the innovativeness dimension and its antecedents,' Journal of Organizational Change Management, 20(3), 429-446.

Sathe, V. (1985). 'Managing an entrepreneurial dilemma: Nurturing entrepreneurship and control in large corporations,' in Frontiers of Entrepreneurship Research, Wellesley, MA: Babson College, 636-656. 
Scott, W. (1995). Institutions and Organizations. Thousand Oaks, CA: Sage Publications.

Sebora, T., T. Theerapatvong, and S. Lee (2010). 'Corporate entrepreneurship in the face of changing competition: a case analysis of six Thai manufacturing firms,' Journal of Organizational Change Management, 23(4), 453-470.

Sharma, P., and J. Chrisman (1999). 'Towards a reconciliation of the definitional issues in the field of corporate entrepreneurship,' Entrepreneurship Theory \& Practice, 23(3), 11-27.

Sine, W., H. Mitsuhashi, and D. Kirsch (2006). 'Revisiting Burns and Stalker: Formal structure and new venture performance in emerging economic sectors,' Academy of Management Journal, 49(1), 121132.

Smith, Y., and J. A. Watkins., (2012). 'A literature review of small and medium enterprises (SME) risk management practices in South Africa,' African Journal of Business Management, 6(21), 6324-6330.

Sorescu, A. B., and J. Spanjol (2008). 'Innovation's effect on firm value and risk: Insights from consumer packaged goods,' Journal of Marketing, 72(2), 114-132.

Stinchcombe, A (1965). 'Social structure and organizations,' in Handbook of Organizations. Ed. J. March. Chicago: Rand McNally, 142-193.

Stopford, J.M., and Baden-Fuller, C.W.F (1994). 'Creating corporate entrepreneurship,' Strategic Management Journal, 15(7), 521-536.

Storey, C.D. and M. Hughes (2013). 'The Relative Impact of Culture, Strategic Orientation and Capability on New Service Development Performance,' European Journal of Marketing, 47(5/6), 833856.

Toledano, N., D. Urbano, and M. Bernadich (2010). 'Networks and corporate entrepreneurship: a comparative case study on family business in Catalonia,' Journal of Organizational Change Management, 23(4), 396-412.

van Wyk, R., and M. Adonisi (2012). 'Antecedents of corporate entrepreneurship,' South African Journal of Business Management, 43(3), 65-78.

Vossen, R. (1998). Combining small and large firm advantages in innovation: theory and examples. University of Groningen.

Wan, W., and R Hoskisson (2003). 'Home country environments, corporate diversification strategies, and firm performance,' Academy of Management Journal, 46(1), 27-45.

Yin, R. (1984). Case Study Research: Design and Methods, Beverly Hills, CA: Sage Publishing

Yin, R. (2003). Case Study Research: Design and Methods, Newbury Park, CA: Sage Publishing.

Yin, R. (2014). Case Study Research: Design and Methods, Newbury Park, CA; Sage publications.

Yiu, D., and C. Lau (2008). 'Corporate entrepreneurship as resource capital configuration in emerging market firms,' Entrepreneurship Theory \& Practice, 32(1), 37-57.

Young, M. N., T. Tsai, X. Wang, S. Liu, and D. Ahlstrom (2014). 'Strategy in emerging economies and the theory of the firm,' Asia Pacific Journal of Management, 31(2), 331-354.

Zahra, S. A., and J. G. Covin (1995). 'Contextual influences on the corporate entrepreneurshipperformance relationship: A longitudinal analysis,' Journal of Business Venturing, 10(1), 43-58.

Zahra, S., and J. Pearce (1994). 'Corporate Entrepreneurship in Smaller Firms: The Role of Environment, Strategy and Organization,' Entrepreneurship, Innovation, and Change, 3(1), 31-44.

Zahra, S. A and M. Wright (2011). 'Entrepreneurship's Next Act,' Academy of Management Perspectives, 25(1), 67-83.

Zahra, S., D. Jennings, and D. Kuratko (1999). 'The antecedents and consequences of firm-level entrepreneurship: The state of the field,' Entrepreneurship Theory and Practice, 24(2), 45-66.

Zellweger, T., and P. Sieger (2012) 'Entrepreneurial orientation in long-lived family firms', Small Business Economics 38(1), 67-84. 